\title{
ニッケル極電位差に就て(第二報) ニッケル極電位差に對する吸藏水素の影響
}

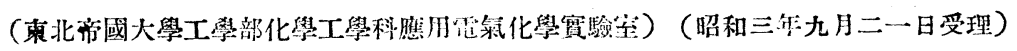

工學士村四空次

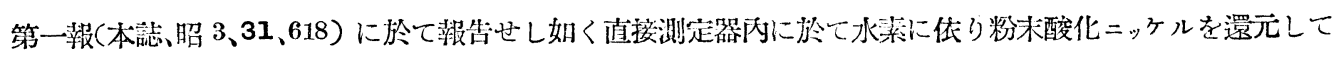

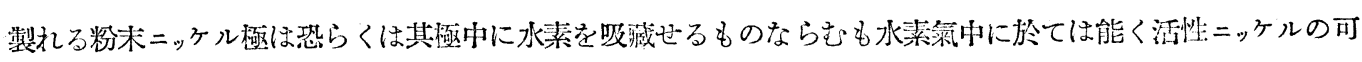

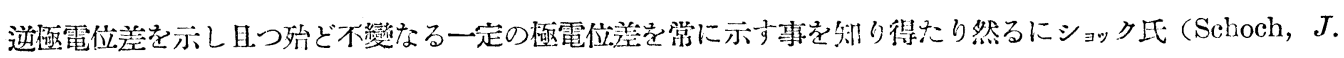
Amer. Chem. Soc., 1909, 41, 208)はニッアル極の呼究に於てリチャーズ圪等(Richards und Pehr, Z. phys.

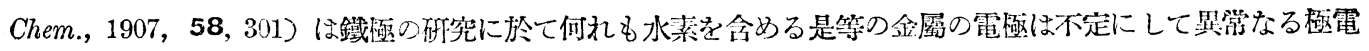

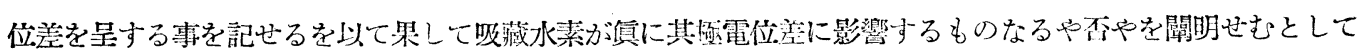
本實驗を企てたるるのなり

チール氏等 (Thiel und Hammerschmidt, Z. Anorg. allg. Chem., 1924, 132, 15)に依るに水菜氣中に於 てニッケルの吸收する水素量は $200^{\circ} \mathrm{C}$ に於て其容積の 0.15 偣 $800^{\circ} \mathrm{C}$ に於て 0.68 㫦にして比較的僅少なるに

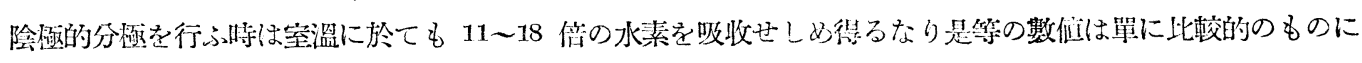

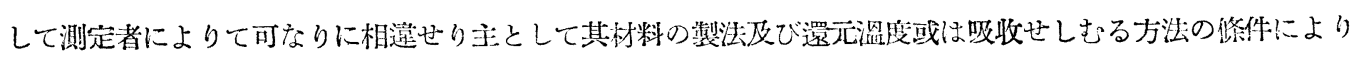
て著るしく槑なる例へばティラー氏等 (Taylor and Burns, J. Amer. Chem. Soc., 1921, 43, 1277) の周到 なる㸴究によれば粉末酸化二ッケルより還元したるものに就きては其還元溫度によりて0.2〜5倍の水素を吸收 し溫度の上良と共に其吸著量は減少すジーベルト氏 (Sievert, Z. phys. Chem., 1911, 77, 591) は $200^{\circ} \mathrm{C}$ 乃至

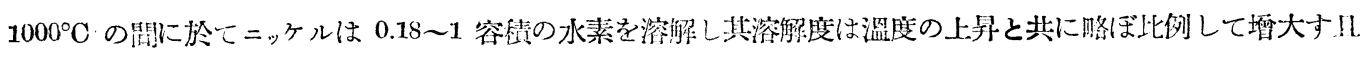

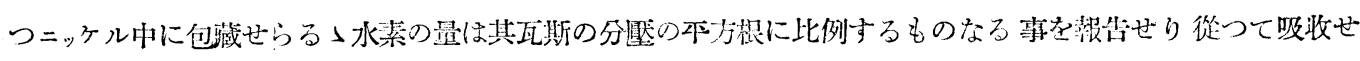

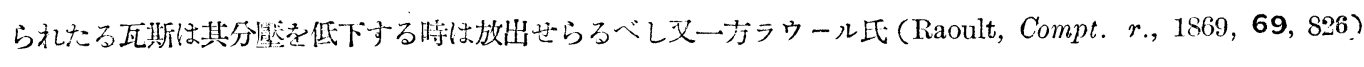

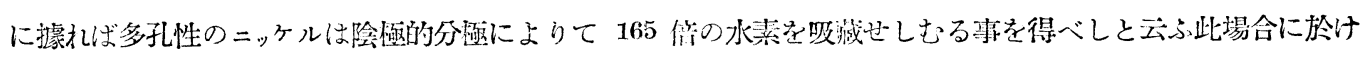

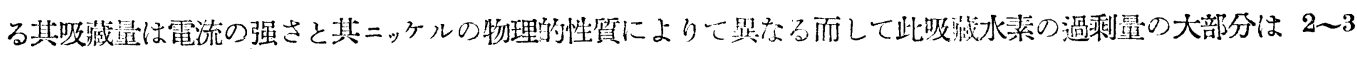

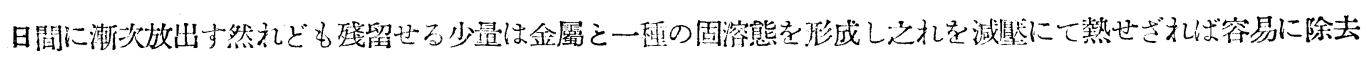
ᄂ得ず

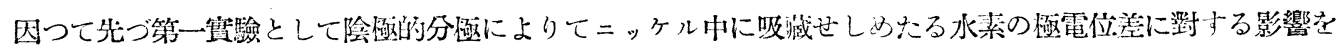

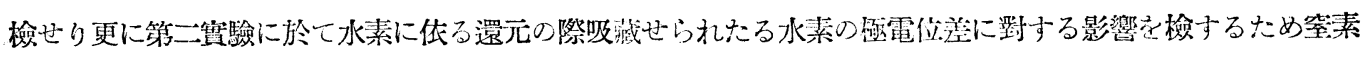
氯中に於计る測定を行へり然るに用ひたる空素中には杼微量の酸素を含む恐れむりしを以て之扎を完全に除去 するため第三賽驗に於て少量の水素を混合せる等素を加熱せるパラヂューム管を通過せしめたる瓦斯を用ひて 第二賽驗に於けると同樣なる賽驗を行へり

\section{装置及び實驗操作方法}

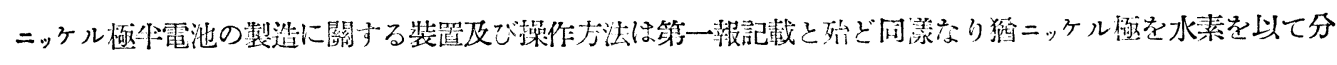
極するに際しては豫め $\mathrm{H}^{\prime}$ なる䝪挀器 (第一報、第一圖、本誌、炤 $3 、 31 、 621$ )に於て $\mathrm{H}$ に於ける電池

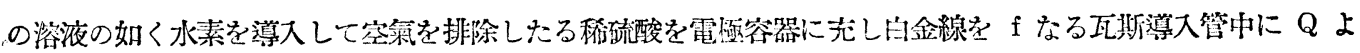


り雨入し之をニッケル極に對し陽極として電流を通じたり分極操作中は此部分より酸液を常に湓出せしめて酸 素の電極部に浸入するを防ぐ榚に注意せり而して可檢溶液を以て良く酸液を洗掃したる後充啃せり

又空素或は少量の水素を混合せし䇪素瓦斯を使用するに當りては還元操作の終りたる後活栓 Q 及び $\mathrm{k}$ を閉 じポンプに依りてiより排氯して電極容器內を減巸として高溫度に放置し次に所用の瓦斯を逗入して置換せり 此操作を數包反復してニッケル極中に含まれたる水素を排除せり他の操作方法は前報記载と略同樣なり

第 二: 娄

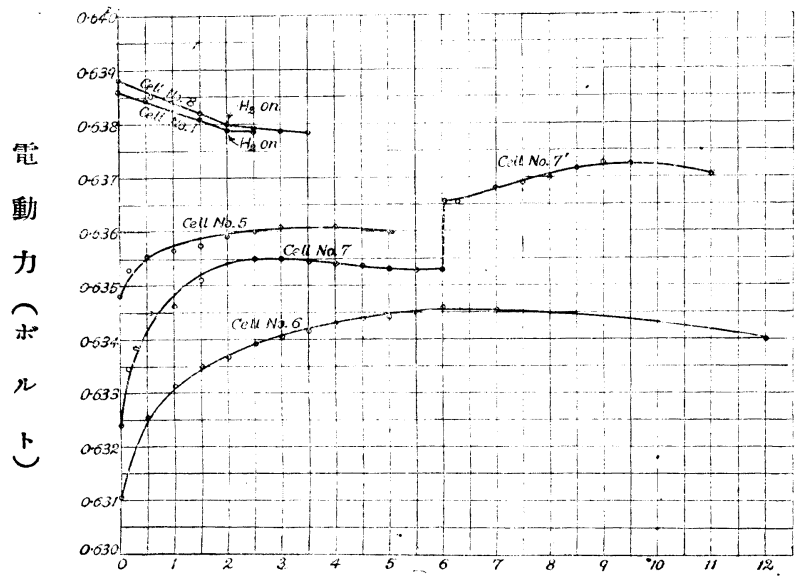

經過日數
電動力の測定結果 测定に用ひし電池の組合せ下の如し $\mathrm{Ni}\left|\mathrm{NiSO}_{4}(0.05 M)\right| \mathrm{KCl}$ 飽和液 | $\mathrm{KCl}(0.1 N) \mathrm{Hg}_{2} \mathrm{Cl}_{2} \mid \mathrm{Hg}$

本實驗に於ては電池の溶液として常に 0.05 $M 、 \mathrm{NiSO}_{4}$ を用ひ $25^{\circ} \mathrm{C}$ の恒溫槽內に於て 測定を行へり

比較に便するなめ實驗結果は第五表に總 括せり唒第二圖に是等各電池の電動力の時 間的變化を圖示せり極電位差は甘承電極の 方常に高位にありたり從つて此電池の電動 力は負號を有寸れども圆には符號を考慮に 入れず單に數値のみにより曲線を畫きたり 表

$\mathrm{Ni}\left|\mathrm{NiSO}_{4}(0.05 M)\right| \mathrm{KCl}$ 飽和液 | $\mathrm{KCl}(0.1 N), \mathrm{Hg}_{2} \mathrm{Cl}_{2} \mid \mathrm{Hg}, \quad 25^{\circ} \mathrm{C}$ 電 動力 测 定 值(ヴォル ト)

\begin{tabular}{|c|c|c|c|c|c|}
\hline 桱過時間 & 第 5 雷池 & 第 6 電池 & 第 7 電池 & 第 7 ' 電池 & 第 8 電池 \\
\hline 1 & -0.6348 & -0.03105 & -0.63240 & -0.63660 & -0.6388 \\
\hline 2 & -0.6350 & -0.63125 & -0.63275 & -0.63660 & -0.6388 \\
\hline 4 & -0.6353 & -0.63130 & -0.63345 & -0.63655 & -0.6387 \\
\hline 7 & 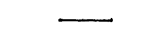 & $\rightarrow$ & -0.6338 & -0.63655 & $\longrightarrow$ \\
\hline 12 & -0.6355 & -0.6326 & - & - & - \\
\hline 17 & - & - & -0.6345 & - & -0.6385 \\
\hline 24 ( 1 日) & -0.63565 & -0.6332 & -0.6346 & -0.6368 & -0.6384 \\
\hline 36 & -0.63575 & -0.6335 & -0.6351 & -0.6369 & -0.6382 \\
\hline 48 (2日) & -0.6359 & -0.6337 & -0.6354 & -0.6370 & -0.6380 \\
\hline 60 & -0.6360 & -0.6339 & -0.6355 & -0.6372 & $\begin{array}{r}-0.6379 \\
\mathrm{H}_{2} \text { 尊入 }\end{array}$ \\
\hline $72(3$ 日) & -0.6361 & -0.63405 & -0.6355 & -0.6373 & -0.63785 \\
\hline 84 & - & -0.63415 & -0.63545 & -0.63725 & $\begin{array}{c}-0.63780 \\
\mathrm{O}_{2} \text { 導入 }\end{array}$ \\
\hline 85 & - & - & - & - & -0.5692 \\
\hline $\begin{array}{l}96(4 \text { 日) } \\
108\end{array}$ & $\begin{array}{r}-0.6361 \\
-\end{array}$ & $\begin{array}{l}-0.6343 \\
-0.6344\end{array}$ & $\begin{array}{l}-0.6354 \\
-0.6354\end{array}$ & - & -0.5868 \\
\hline 120 (5 日) & -0.6360 & -0.6344 & -0.6353 & $\begin{array}{r}-0.63705 \\
\mathrm{O}_{2} \text { 導入 }\end{array}$ & 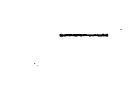 \\
\hline 121 & - & - & - & -0.5984 & $\longrightarrow$ \\
\hline
\end{tabular}




\begin{tabular}{|c|c|c|c|}
\hline 132 & $-0.63 \pm 5$ & -0.6353 & -0.6233 \\
\hline $144(6$ 日) & -0.6346 & -0.6353 & - \\
\hline 168(7日) & -0.63455 & - & - \\
\hline 288 (12日) & -0.6340 & $\longrightarrow$ & - \\
\hline 289 & $\begin{array}{c}\mathrm{O}_{2} \text { 導入 } \\
-0.5612\end{array}$ & - & - \\
\hline
\end{tabular}

（Ｉ） 分極水素の影響 第 5 電池の電齔材料は第 1 電池のそれと全く同樣にして製れるものにし

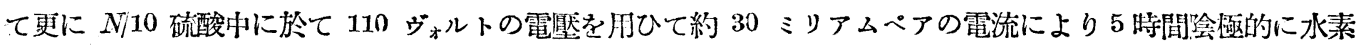
を以て分通せり分唃操作は可なり注意して行ひたりと信ずるも此電池の電動力測定の初期に於て其各個の電極 電位差の觀測値は屡々相互に 1 ミリヴォルト近くの差異を亦したり

第 5 電池の测定結果より觀らるる如く第 1 電池の電動力より少しく小にして水素氯中にて還元して製りた る電極は更に陰樋的に水素を以て分樋するもシュワイッァー氏 (Schweitzer, Z. Elektrochem., 1909, 15, 607)

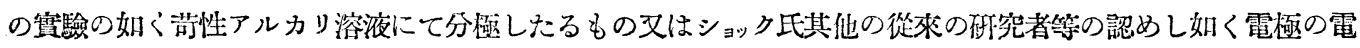
動力を增大する事なくヌリチャーズ氏等（前揭）が鐵に於てシルドバッハ氏 (Schildbach, Z. Elektrochem.,

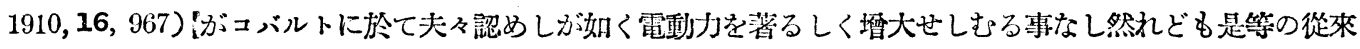
の呼究者等によりて使用せられし電極は總て其製造操作中に於て空氣と接觸する機會あるものなり

第 5 電池の最初の值は㐨期に反し第 1 電池のそれより約 4 ミリヴォルト小なる電動力を示せり此測定の初め に於ける極電動力の減少に就きては不幸にして直接實驗する機會を得ず今茲に斷言し得ざれども少くも其一部 は遊離酸の影響に因れるものと考へらる其は分極用の酸の微量は残留する恐れむり而して藷者の方法に依りて

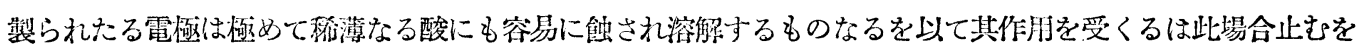
得ざる事なり從つて其影響を教慮せざるべからざるなり之れを他の例に徴するに既にショック氏はニッヶル極に 於ける遊離酸の影響に就て實驗し其極微量の存在に據りても極電位㾤は落るしく減少する事を記せり猫同樣な る酸の影響は著者の鐵極電位差の鿓驗(未發表)に於ても認められたり

（II）堂素隶中に於ける測定 第 6 並に第 7 兩電池の電極材料は何れと第 1 電池のそれと同樣 にして酸化粉末ニッケルを水素氣中にて還元したるものな扎ども更に其水素を窒素により高溫に於て置換せし めたり但し第 6 電池に於ては其水素を置換するに單に窒素瓦斯每秒 2 3 泡粒の速度 (約 $50 \mathrm{cc} /$ 分) にて極容 器中を通過せしめ流掃せしのみなれども第7 電池に於ては既に記述せし如くポンブを用ひて減區し吸藏水素の 完全なる排除を期したり之等兩電池に用ひたる浴液は同一夥敬溶液より同樣なる操作によりて調製し含有せる 空氣を豫め空素を以て置換せり

偖之等兩電池の結果は第二圖に示せる如く殆ど同一型の曲線を示し其最初の値は第 1 電池に比し何れも可な り小にして初めに於て急激に習大し後には殆ど一定となれり是等の電池の個々電㥛の値は水素氣中に於ける測 定の場合と同椪同一電池內に於ては相互に良く一致し其偏差は僅に 0.05 ミリジォルトに過ぎず然るに是等兩電 池の最初に於ける電動力の間には 1.4 ミリジォルトの相逗あり餘りに大にして筫驗誤差としては做し得ざるも のなり

而して第 7 電池の測定 6 洔間の後其溶液を第 1 電池の溶液の如く豫め水素にて飽和せし溶液を以て置換 したるに其電動力は殆ど直ちに 0.6366 ボルトに㬐大し後には徐々に數日にして 0.6373 ヴィトに達し第 1 雷 油の值に接近せり第 $7^{\prime}$ 電池とせしはそれなり 
第 6 並に第 7 兩電池の初めの電動力が第 1 電池のそれに比し小なるはニッヶルの極中に含まれたる水素の 排除に因れる如く思考せられしも份良く之れを考察寸るに第 7 電池の初めの電動力は第 6 電池のそれよりる 大にして第 7 電池の電極の減巸排氮操作は第 6 電池に此し其極中に吸藏せられたる水素の排除に一曆有効な るものと思はるるを以て若し其變化の原因を吸藏水素に求むる時は其電動力は一層減少すべき筈なるに結果は 全く反㖶なり因つて他に其原因を求むるに用ひし空素の純度の不足に求むる時は是等の事實は凡て明かとなる むのなり

是等の惯驗に使用せし空素は媱時空素㸴究所より分與されしものにして液體空氮より分別せしものなり不純 物として $2-3 \%$ の酸素を含有せるものなり之れを普通の方法に從ひアルカリ性過マンガン酸加里溶液を有す

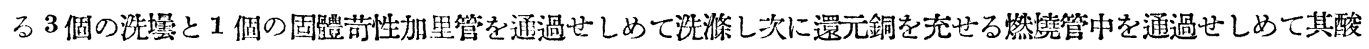
素を除去し更に固踣䓅性加里管を通して乾懆したり然るに之れを文獻に徵するに空素中に含まるる極微量の酸 素は上記の如き普通の方法によりては到底完全に除去し得ざる事を明記せり(例へば Kautsky und Thiele, $Z$. anorg. allg. Chem., 1926, 152, 342)丈ニッケルの酸素に對する作用は强烈なるを以て俌用せし窒素中に含まる る極めて微量の酸素も影饗し得る事ば考へ得らるべし而して第 6 電池に用ひし莹素量は第 7 電池に用ひたる・ 是に比し遥に多昷なりしを以て其影響も大なりしものなるべし別に是等の電池に微量の空氣を導入して訌驗せ

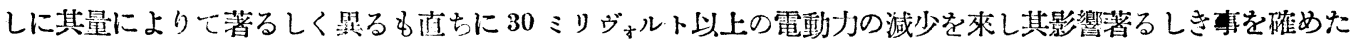
り因つて第 6 並に第 7 雨電池の初めの電動力が第 1 電池のそ机に比し小なりしは空素中に殘留せし微量の 酸素の作用が其原因なりしを示さものなるべし

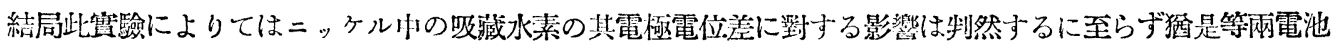
に於て永めの電動力が漱次哂大するに就きては後の第三報に於てニッヶル不働態の復活機構と共に論究する處 あるべし次に第 $7^{\prime}$ 電池に於て其溶液を水素を含む溶液と置换したる際に亦したる電動力の急激なる霄大に就 き考察するに此戀化は上記の第 7 電池の初めに於ける電動力の減少と密接なる關係にあるべく思惟せらる又シ

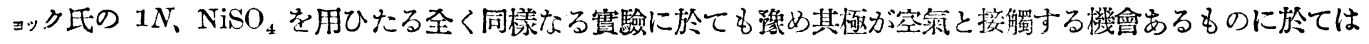
之れに水素を導入する事により直ちに 100 ミリヴォルト以上の急激なる增大を示し 0.337 ヴォルトの異常に高き 電動力を呈せり著者の $0.1 \mathrm{~N} 、 \mathrm{NiSO}_{4}$ 溶液に於けるニっアル極電動力の實測値より $1 \mathrm{~N} 、 \mathrm{NiSO}_{4}$ 溶液に於ける 電㥛電位差を算出寸狄 0.276 ヴォルトとなれり是等の事實と藷者の第 1 電池の場合に於ける水素瓦斯導入に 於ける結果とを照合する事により豫め空氣との接觸等によりて酸素の影響を蒙れる極に於ては水素による影響 も一層著しきを知れり

此第 7 電池の思激なる變化は其溶液中に溶解せる水素とニッケルとの接觸に於て瞬間的に起りたる電極の變 化に據れるものなる事は疑ふを得ず從つて此水素の極に對する作用は極めて皮相的のものなりと推考せらるる も斯くの如き急激なる變化が此電池の牀態に於て電極による水素の單なる物理的吸著によりて起るものとは考 ヘられず

從つて此第 $7 '$ 電池の電動力の急激なる變化は此電池に使用せし窒素氣中に殘留せし微量の酸素によりて豫 て酸化せられたる電極面の水素による還元に原因せるものと考へらるべし然れども唒水素の水素極としての作 用も考へざるべからず此問題を解決せむため少量の水素を混合せる窒素を用ひて次の實驗を行ひニっヶル極電 位差に對する其吸藏水素量の變化の影響を檢せり

（III） 水素を含有せる窒素半中に於ける测定 第 8 電池の電㥛材料は第 7 電池のそれと同 
樣にして製りたるものにして唯案素㯃の代りに水素 1 部と窒素 9 部*とよりなれる混合瓦斯を加熱せるパラ ヂュウム管を通過せしめて其瓦斯中の酸素を完全に除去したる後其過剩なる 少最の水素を含めるものを使用せ り電峺は $300^{\circ} \mathrm{C}$ に於て此混合瓦斯中に約 1 時間放置して氣相中の水素分匬と二ッケル極中の吸藏水素との平衡 に達せしむる樣にせりり

第 8 電池の電動力は純粹なる水素氣中に於ける第 1 電池の電動力と全く间一なる估を示し其變化の經過も 全く同樣なりき今此實驗結果より推考するにニッケル極は水素を吸藏する事により極電位差に變化を生ずるも のに非ざるを知るを得べし其は若し幾分たりとも其影響ありとせば第 8 電池の電位差は第 1 電池と第 6 電 池との値の中間値を示さざるべからざればなり**

又ス ミッツ氏等 (Smits and Lobry du Bruyn, Proc. Acad. Sci. Amsterdam, 1918, 20, 394; Smits, “Die Theorie der Allotropie” 1921, S. 412) の報告せる如くニッケル極が触際水素極として働き得るものと せば水素の分嬮に於て少くも 20 倍の相違あるを以て第 1 電池の侱に比し約 0.08 ヴォルトの電位差の差異を呈 すべき䈏にして結果と合致せず從つて第 7' 電池に於て水素による極電位美の急激なる變化は比較的不活性狀 .態にある該表面が水素により化學變化を受け活性紎態に復活せしによるものなりと推断する事を得るなり此復 活機構に就きては第三報に於て詳細に論究せむとす

要するに本實驗によりてニッケルの場合に於ては其四藏せられたる水素は其稹の極電位差に何等影響せざる 決論に到達せり從つてニッケルの極電位差の測定に於て最も朋要なる條件は酸素の影暨を全く遮楽するにむり 而して水素氣中に於ける測定は酸素の影響を全く遮钫せしむるに便宜なるものなり

伏屋㪍授の懇篤なっ御指導に對し梁謝の意方表す

$$
\text { 總括 }
$$

1 水素 1 氣迮つ下にある $\mathrm{Ni}\left|\mathrm{NiSO}_{4}(0.05 M) \| \mathrm{KCl}(0.1 N), \mathrm{Hg}_{2} \mathrm{Cl}_{2}\right| \mathrm{Hg}$ なる電池に於て其のニッケル 極を稀硫酸液中にて陰極的に水素を以て分極するも其の電池の電動力は何等增大せしむるを得ず此除極的分極 に体りてニッケル中に四藏せしめたる水素の極電位差に對寸る影響は從來の研究者が一般に鐵族の金屬に於て 認めたる結果と全く暴なれり著者の場合に於ては却つて少しく小なる電動力を示せり此測定の初期に於ける電 動力の減少は恐らくは殘留せる微量の遊離酸の影響に據えるものなるべしと思惟す此際分極用酸の残留する恐 れあるは止むを得ざる事なればなり

2 窒素氣中並に少圔の水素を混合せる空素爾中に於てニッケル極電位差の測定を行へり是等の筫驗結果よ りニッァル中に於ける吸藏水素は何等其の盾の極電位差に影響せざる決論に到澾せり然れども豫め酸素との接 觸に体りて其の作用を蒙れるものに於ては水素の導入に依りて室溫に於ても速に活性に復しニッァル不働態に 對する水素の影響の著るしき事を知るを得たり

3 ニッケル極電位差の測定に於て最も朋要なる條件は酸素の影響を全く遮斷するにあるなり

* 此實驗に使用せし混合瓦斯は瓦斯町藏器の $20^{\circ} \mathrm{C}$ の水上に一旦眝藏したろ後使用に供したるる以 て瓦斯中の酸素と其貯藏器の水中に溶解せる酸素とか完全に除去するに要す万充分なる水素量は著 者の計算によるに窒素瓦斯容積の粎 $8 \%$ となれり水中に溶解せる酸素量は $20^{\circ} \mathrm{C} に$ 於け万空氣の溶 解度と其貯藏器の容量とより計算せり此際瓦斯中に殘留せる水素の量は分析せざりしも空素中の酸 素の量より多くと65\%古出てざら事は明なりき

** =ッケルによりて吸藏さられたら水素量がジーベルト氏(前揭)の報告せる如く水素分胙の本方根. に此例する6のとせば第 8 電池のニッケル極中に吸藏せられたる水素量は其使用せし瓦斯中の水素 量が $5 \%$ 以下なるべきか以て第 1 電池に於けるそれの 22/100以下ならざるべからず 